\title{
Secularization, Modernity, and Belief Shaping: Night School and Livelihood Education at the Chinese YMCA in the Early Twentieth Century
}

\author{
Yi Yang ${ }^{1}$, Xunqian Liu ${ }^{1, *}$ and Kuan-Yu Ko ${ }^{2}$ \\ 1 School of Humanities, Shanghai Jiao Tong University, Shanghai 200240, China; 11904yang@sjtu.edu.cn \\ 2 Divinity School of Chung Chi College, The Chinese University of Hong Kong, Shatin, Hong Kong; \\ W87293672@163.com \\ * Correspondence: a0103212@163.com
}

Citation: Yang, Yi, Xunqian Liu, and Kuan-Yu Ko. 2021. Secularization, Modernity, and Belief Shaping: Night School and Livelihood Education at the Chinese YMCA in the Early Twentieth Century. Religions 12: 897. https://doi.org/10.3390/rel12100897

Academic Editor: Fida Sanjakdar

Received: 17 June 2021

Accepted: 15 October 2021

Published: 19 October 202

Publisher's Note: MDPI stays neutral with regard to jurisdictional claims in published maps and institutional affiliations.

Copyright: () 2021 by the authors. Licensee MDPI, Basel, Switzerland. This article is an open access article distributed under the terms and conditions of the Creative Commons Attribution (CC BY) license (https:// creativecommons.org/licenses/by/ $4.0 /)$.

\begin{abstract}
In the early 20th century, influenced by evangelicals in the United States, the Young Men's Christian Association (YMCA) launched the "Four Movements" in response to the "Four Maladies" of Chinese society. Among the four movements, "livelihood education" is used to help raise productivity and save people from poverty. Research on the YMCA in modern China rarely focuses on livelihood education, and even when it does, it does not focus on educated adult civilians or explore how the YMCA has changed the course of their lives. Based on fieldwork and detailed analysis of historical documents, this paper traces the formation of three night schools that have adopted various forms of "Christianized" and "secularization" practices and sheds light on the lives of two typical students whose experiences in YMCA night school were still less known. This study will demonstrate and analyze the role of livelihood education in introducing Western civilization and Christian ideas to China's labor class. YMCA night schools not only helped ordinary Chinese working people acquire basic livelihood skills on a secular level, which enables them to enter a higher class in society and exert influence, but also reshaped their beliefs.
\end{abstract}

Keywords: Chinese Christianity; livelihood education; YMCA; evangelicals; secularization

\section{Introduction}

The Young Men's Christian Association (YMCA) was founded by George Williams in London in 1844; the mission is to promote the moral integrity of young Christians through solidarity programs and civic training and deliver projects and services focused on youth development. At approximately the same time, after the First Opium War, the Treaty of Whampoa, which was signed by Qiying and Théodore de Lagrenéon on 24 October 1844, legalized the practice of Christianity in China. After the Second Opium War, which began in 1856, the Treaty of Tientsin in 1958 allowed Christian missionary activity (Wang 2005, p. 16). The spread of Christianity ran like a rich thread through the fabric of China's turbulent nineteenth century.

In 1885, the YMCA adopted "did not come to be served, but to serve (Gospel of Mark 10: 35-45)" as its motto upon its spread to China. Later, the missionary form was soon accepted and extensively promoted in different parts of China, thus turning the YMCA into a nationwide youth organization. The YMCA did not limit its members to Christians. Instead, it united and served people with different beliefs. As long as one wanted to join it, the YMCA offered membership to him or her.

Under the era background where China of the late Qing dynasty experienced enduring impoverishment and long-standing debility, domestic turmoil, and foreign aggression, the Chinese YMCA, affected by the ideological trend of social gospel, further clarified its guideline of "serving the society and people" and positioned its main development goal to bring up youths into talents with all-around development-morally, intelligently, 
physically, and in terms of social work. The YMCA launched four movements considering the "four ills" of Chinese society. Through cultural education, the YMCA attempted to improve Chinese literacy and stimulate Chinese people to fight for themselves rather than yield themselves to suppression. Through livelihood education, the YMCA aimed to foster productivity to help the Chinese eliminate poverty. Through hygiene education, the YMCA hoped that it could improve Chinese health and change their weak impression in the international arena through citizen education (Annual Report of CYMCA of Shanghai 1901, p. 1). The main method included providing athletic facilities, holding classes for a wide variety of skills, and promoting Christianity and humanitarian work.

The livelihood educational movement was greatly expanded with the opening of what was informally known as the Night School (officially the Evening Institute of the YMCA). Through the night school, the YMCA offered evening classes to working adults with low levels of education and skills. More specifically, the curriculum was designed to meet the needs of three types of young people: those who had missed the opportunity for a general education due to poverty, those who wanted technical training, and those who were simply interested in personal growth (Chen 1927).

Therefore, the YMCA played an irreplaceable leading role in popularizing education in modern China. Mr. Chen Liting, President of Shanghai YMCA, wrote the following in his article in 1927: "The YMCA shares the objectives with other schools, but its teaching methods and facilities are different from the latter. School education is usually provided for part of the people, while the YMCA aims at spreading education to every citizen ... Everyone, either old or young, rich or poor, is included in the educational scope of the YMCA. Therefore, the YMCA can be a vigorous supple-mentation to the lack of national education in China (Chen 1927, p. 13)".

In what follows, the paper discusses how the YMCA became involved in adult education in early twentieth century China, and enabled many young adults to attain a higher socioeconomic status by entering a profession. Through some cases of YMCA night schools in the three most important big cities-Peking, Shanghai, and Guangzhou-this paper is dedicated to introducing the basic status of YMCA livelihood education that once wrote an important chapter in China's history of Christianity. Furthermore, the YMCA livelihood educational system (also known as night schools for workers), together with how the educational system influenced and decided the education receivers' belief reshaping and concept changes, is examined.

\section{Literature Review}

Among today's research work on the Chinese YMCA's educational activities, academic circles have shown more interest in studying how the YMCA applied its Christian ideas and concepts to the social and political layers through its moral role in shaping citizenship education rather than education for subjects of a feudal ruler. Citizenship education not only builds an ideal model for Christians to participate publicly in the political sphere, but is also related to the meaning and practice of political citizenship in modern China (Bai 2020; Goldman and Perry 2002).

Livelihood education, which has a close bearing on the basic survival status of ordinary workers, or to put it more bluntly, the urban poor, is otherwise less investigated. A few significant English-language studies have pointed out that the YMCA's most significant contribution to Chinese society was the non-traditional educational opportunities it provided to many urban working-class people (Garrett 1970; Perry 1993; p. 160). Far more common, researchers hold a neutral or even suspicious attitude toward livelihood education that taught secular work skills that were practical and superficially irrelevant to Christianity rather than preaching Christianity practices among citizens from the spiritual layer, and the livelihood education wavering its identity between a church or a part of social work (Xing 1993; Zhang 2010; Huang 2013).

Even though the main purpose of public service is to service those people who need help, it looks like a bright spotlight, mainly focusing on the folks who do the service, 
rather than the people that we serve. The "darkness under the light" phenomena can also be found in relevant research on the Chinese YMCA livelihood education. Although some researchers have already covered YMCA livelihood education in their work, they mostly proceed from the educators' stance to review their contributions and proposals from a superior perspective. They interpreted secular educational concepts and educational systems from the perspective of educators rather than from the perspective of the masses regarding how to change the track of their daily lives and even the spiritual faith of ordinary Chinese. Western and Chinese missionaries proposing educational ideas, developing educational plans, and implementing educational concepts gained the most attention. For example, the relevant educational theories and social practices, David Z. T. Yui (1882-1936) and Y. C. James Yen (1890-1990), who were pioneers of the movement of education for the masses in the Chinese YMCA (Hayford 1979; Chung 2019). Previous histories of the YMCA education, and of the Chinese association specifically, have not adequately tapped the vast literature of the night school of the YMCA. Hence, this paper focuses on education receivers and seeks to understand how developments in YMCA livelihood education contributed to social welfare and the ongoing search for beliefs by individuals. In short, to understand the other side of the Chinese YMCA and its educational enterprise, it is essential to apply insights into the development process of the YMCA night school during the livelihood education movement in the early 20th century.

\section{Research Aims and Methods}

This paper aims to describe the establishment and purpose of Chinese YMCA night schools for workers, their main programs and mission, and the teaching achievements in the early twentieth century. Hence, primary sources, secondary sources, and archival sources derived from fieldwork were drawn on. Data collection was conducted from the archives and libraries of Mainland China, Hong Kong, and the USA, such as the Shanghai Library, the Shanghai Archive, the Guangzhou Archive of China, Fung Ping Shan Library, YMCA Historical Library, and Kautz Family YMCA records. The sources used in the study consist of records of missionary educational institutions, reports, diaries, or memoirs of famous YMCA leaders.

We tried to use documents from various places to create a general profile of the YMCA night schools. Why did the Chinese YMCA start night school? Who attended and graduated from those night schools? Who were the faculty and who taught the courses? What sort of curriculum and instructional methods were used? What were the entrance requirements of the schools? By identifying these sources, evaluating their relative authority, and combining their testimony appropriately, an accurate and reliable picture of past events and environments can be constructed.

We further point out the value of utilizing a diverse array of historical sources. When evaluating the contribution of the night schools to bringing education to the urban working class, our efforts to interpret YMCA livelihood education's influence on Chinese society are greatly enhanced.

\section{Result}

\subsection{The Establishment and Purpose of the YMCA Night Schools for Workers}

In 1898, R.E. Lewi, general secretary of the North American and Canadian YMCA, went to Shanghai to organize the YMCA educational work there. R. E. Lewi invited Cao Xuegeng, who was teaching at the Anglo-Chinese College, to be his assistant, and he invited dozens of prominent people in Chinese society, including Yan Huiqing, Huang Zuoting, Song Yaoru, and others, to engage in joint planning (China YMCA National Association 1935, p. 175). On 6 January 1900, the Shanghai YMCA was established (Annual Report of CYMCA of Shanghai 1901, p. 1). At the very beginning, the Shanghai YMCA established its English night school. In the beginning of the Articles of YMCA for the Night School, Anonymous (1912), Shanghai YMCA describes its purpose as follows: 
"Time is money; hence precious time should be spent on studying. Many brothers did not complete basic education and went into business because they needed to make a living. However, they soon discovered they could not read or write and had no basic knowledge. In this competitive society, if people do not have a skill, they will soon be eliminated. Therefore, we started night school".

In the early 20th century, under the influence of social gospel and the "Student Volunteer Movement for Foreign Missions", the YMCAs of some American universities started selecting their best missionary bases in Chinese cities. Peking, the capital city of China, became the top choice of Princeton students. In 1906, the Princeton-Peking Center was established to start preparing the founding of the Peking YMCA. In 1909, the Peking YMCA was finally established (Zuo 2003; Bean 2012). Its English night school was founded in the same year. In the Articles of Association for the English Night School 1929, the Peking YMCA introduced its school's history like this:

Different countries have different languages and cultures. If civilizations want to communicate with each other, they need to know each other's language first. But people with jobs have no time to study during the day time, hence we started the English night school in 1909.

Founded in 1908, the Guangzhou YMCA was established. In 1909, it established the English night school. In the 1912 work report, the missionary F.E. Wilber stated that he taught students in English at the night school and that students were young business persons or employees interested in learning English (Guangzhou YMCA 2019, p. 49). In 1918, general secretary E.H. Lockwood, while studying how to expand the running scope of night schools (the previous YMCA night schools were limited to mainly providing Bible classes and English classes), thought that attention should be continuously given to those having no access to school education (Guangzhou YMCA 2019, p. 221). In 1922, G.E. Lerrigo's report also said that the Guangzhou YMCA would continue strengthening its ties with the working class and improving its influence on this group of people.

Since then, the YMCA night school has begun to mainly enroll workers without a systematic education. In terms of enrolment conditions, there are only two requirements for students: one is age and the other is morality. As for the age of students, the school had adjusted from the initial age of 14 to the later age of 16 . The moral character requirements included honesty, hard work, and respect for others.

In 1929, the report entitled "YMCA in Guangzhou: Talent Development Takes Years of Efforts" stated that night schools target employees deprived of education and youths from impoverished families. Furthermore, it said, "In Guangzhou with a large number of universities, there were still many people having no access to education. In order to make a living, they had to engage in all kinds of work in the daytime. We set up our school as a supplementation to the defective educational cause. Therefore, all our subjects emphasized learning practical knowledge (Guangzhou YMCA 2019, p. 278)". In 1933, the Guangzhou YMCA mentioned in its educational report again that night school was for the purpose of improving workers' skills to make a living and improve their social status and wellbeing (Guangzhou YMCA 2019, p. 305).

\subsection{Main Programs and Mission}

In 1901, Shanghai YMCA night school offered classes for English, French, and German that lasted for eight months. In 1903, the night school introduced subjects related to skill development, such as accounting, typing, math, and official document translation (Annual Report of CYMCA of Shanghai 1903, p. 2).

After establishing the English night school, the Shanghai YMCA established the Business Day School and gradually developed into the famous YMCA high school in Shanghai. The high school offered night courses in business, English, accounting, document preparation, stenograph, business administration, trade, car driving, etc. (Articles of YMCA for the Business Night School, Anonymous 1915, p. 1). Figure 1 shows the cars used to teach the driving course at Shanghai YMCA night school. 


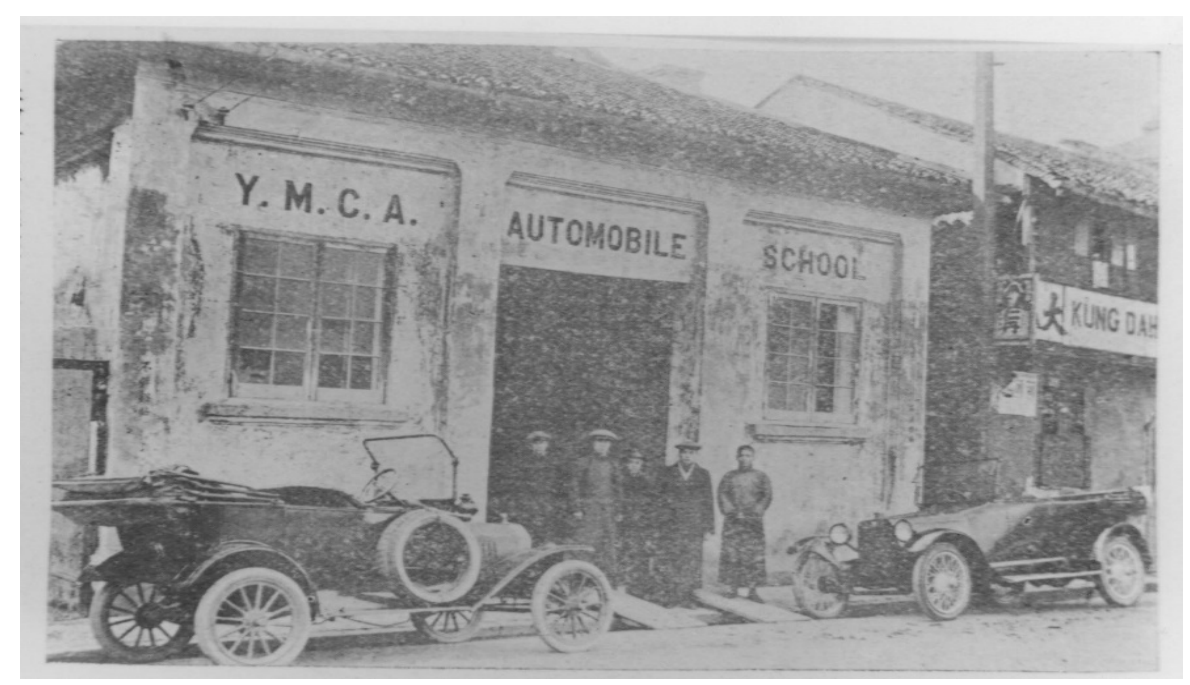

Figure 1. Shanghai YMCA opened car driving course (the original photo is in the Shanghai Library).

Zhang Zhiwei said that all the on-the-job students studying in the night school attempted to reach new heights in business circles (Zhang 2010, p. 179). Obviously, the organizers of the Shanghai YMCA night school were very clear about students' utilitarian purpose of learning. Therefore, they consciously combined their missionary work with the night school from the very beginning. In 1903, when the night school was initially established, the YMCA provided English Bible classes free of charge for night school students from 7:00 p.m. to 8:00 p.m. on every Wednesday. Furthermore, it established the English Bible Study Group for night school students under the premise of helping students with their English learning (Homework Sheet, Anonymous 1924). In addition, YMCA members paying night school tuition fees could get $50 \%$ off; the tuition fees were 1 yuan per person for YMCA members and 2 yuan per person for nonmembers. This is the main method that the YMCA used to attract students to join Christianity. As one observes in the course schedule for the Shanghai YMCA 1912, the courses provided free of charge, including religion and ethics and English Bible, attracted the most students (Articles of YMCA for the Night School, Anonymous 1912). The other courses were provided in small classrooms, but the above two courses were given in the big auditorium (as can be seen in Table 1).

Table 1. Night school schedule of Shanghai YMCA 1912 (data from Articles of YMCA for the Night School, Anonymous 1912).

\begin{tabular}{|c|c|c|c|c|c|c|c|c|c|c|}
\hline Subject & Mon & Tue & Wed & Thu & Fri & Sat & Room & Instructors & $\begin{array}{c}\text { Fees } \\
\text { Memb's }\end{array}$ & $\begin{array}{c}\text { Fees } \\
\text { N.Memb's }\end{array}$ \\
\hline English, Primer & $7-9$ & $7-9$ & & 7-9 & $7-9$ & $7-9$ & 43 & Mr.O.Z,Lee & 6 & 11 \\
\hline English, I, Reader & $7-9$ & $7-9$ & & $7-9$ & $7-9$ & $7-9$ & 43 & Mr.O.Z,Lee & 6 & 11 \\
\hline $\begin{array}{l}\text { English, II, } \\
\text { Reader }\end{array}$ & $7-9$ & $7-9$ & & $7-9$ & $7-9$ & $7-9$ & 44 & Mr.C.Y.Hsu & 6 & 11 \\
\hline $\begin{array}{c}\text { English, III, } \\
\text { Reader }\end{array}$ & $7-9$ & $7-9$ & & $7-9$ & $7-9$ & $7-9$ & 44 & Mr.C.Y.Hsu & 6 & 11 \\
\hline $\begin{array}{c}\text { English, IV, } \\
\text { Reader }\end{array}$ & $7-9$ & $7-9$ & & $7-9$ & $7-9$ & 7-9 & 46 & Mr.A.S.F.Chur & 6 & 11 \\
\hline $\begin{array}{c}\text { English, V, } \\
\text { Reader }\end{array}$ & $7-9$ & 7-9 & & $7-9$ & $7-9$ & 7-9 & 46 & Mr.A.S.F.Chur & 6 & 11 \\
\hline $\begin{array}{l}\text { English, } \\
\text { Advanced }\end{array}$ & $8-9$ & & & $8-9$ & $8-9$ & & 47 & & 6 & 11 \\
\hline French & $8-9$ & & $7-8$ & & $8-9$ & & 42 & Mrs.G.A.Fitch & 7 & 12 \\
\hline Mandarin & $6-7$ & $6-7$ & & & $6-7$ & & 48 & Mr.C.T.Lieu & 5 & 10 \\
\hline Chinese Classics & $6-7$ & $6-7$ & & & $6-7$ & $6-7$ & 42 & Mr.Y.C.Chow & 5 & 10 \\
\hline
\end{tabular}


Table 1. Cont.

\begin{tabular}{|c|c|c|c|c|c|c|c|c|c|c|}
\hline Subject & Mon & Tue & Wed & Thu & Fri & Sat & Room & Instructors & $\begin{array}{c}\text { Fees } \\
\text { Memb's }\end{array}$ & $\begin{array}{c}\text { Fees } \\
\text { N.Memb's }\end{array}$ \\
\hline Translation & & $7-8$ & & $7-8$ & & & 42 & Mr.N.Y.Chang & 3 & 8 \\
\hline Book Keeping, I & & $7-8$ & & & $7-9$ & & 42 & Mr.F.Francis & 7 & 12 \\
\hline Book Keeping, II & & $8-9$ & & & $7-9$ & & 41 & Mr.F.Francis & 7 & 12 \\
\hline Book Keeping, III & & $8-9$ & & $7-9$ & & & 42 & Mr.R.W.Waccabe & 7 & 12 \\
\hline Typewriting & $8-9$ & & $7-8$ & & $8-9$ & & 48 & Miss Brooks & 12 & 17 \\
\hline $\begin{array}{l}\text { Commercial } \\
\text { Practice }\end{array}$ & $8-9$ & & $7-8$ & $8-9$ & & & 48 & Mr.G.B.Fryer & 7 & 12 \\
\hline $\begin{array}{l}\text { Religion and } \\
\text { Ethics }\end{array}$ & & & & & & $7: 45-8: 15$ & M.M.Hall & & & \\
\hline English Bible & & & $7-8$ & & & & $\begin{array}{c}\text { Lecture } \\
\text { Hall }\end{array}$ & & & \\
\hline
\end{tabular}

The Peking YMCA night school first provided the school students with English classes, typing classes, and occupational classes. Every academic year was divided into two semesters. Students were expected to finish their studies and pass the examinations in four years. Western teachers were the majority and there were also some erudite Chinese teachers with rich teaching experience (Peking YMCA 1929, pp. 2-3). These teachers all graduated from European or North American universities with degrees no lower than a bachelor's degree. The tuition fees for each semester of the English Night School were 15 yuan, but in order to give access to the impoverished students from civilian families, the Peking YMCA English night school established the civilian branch for public good in 1925 (Peking YMCA 1929, p. 8).

"Considering the urgency to provide education for civilians, the civilian branch was set up by our school in the 13th year under the reign of the Republic of China. All teaching and administrative staff are obliged to teach, so there is no need for students to pay tuition fees and fees for books. The night school provides a four-month crash curriculum. So far, we have brought up around five generations of graduates, and the total number of graduates has been around 100 (Peking YMCA 1929, p. 1)".

In 1916, the Guangzhou YMCA night school, which was suspended because of club construction, was relaunched. The teaching objectives of the Guangzhou YMCA night school include enabling students to: (1) write articles and letters; (2) use an abacus to calculate numbers and record accounts; (3) understand the common sense of society and national affairs; (4) have good moral values and social responsibilities (Zheng 2019). The curriculum at that time covered English, bookkeeping, typing, statistics, and many other subjects important to social development under planning. In 1934, the YMCA night school introduced new subjects, including machinery, drawing, Chinese, industrial chemistry, business, nursing, etc. Several general secretaries of the Guangzhou YMCA reported that night schools that targeted working people were of public benefit and did not charge students tuition fees as a measure to help youths. The subject content was practical and simplified, which could help students be competent in different positions and also cultivate their personality (Guangzhou YMCA 2019, p. 308).

According to the difference in students' knowledge level, the Guangzhou YMCA night school divided them into three classes of Grade A, B, and C, and formulated corresponding teaching objectives and teaching methods for the students at each level. Students could only upgrade if they passed the requirements. The school stipulated that "any student with excellent performance in school may be allowed to skip grades or be given a considerable reward. Those who are absent from any subject in a semester for more than one fifth of the total teaching hours shall not participate in the test or final examination. (Guangzhou YMCA 1934)" In addition, the school also used the method of "priority refund of the deposit" to stimulate students' motivation to complete learning tasks. 
The night school had also formulated strict regulations on the graduation conditions of students: "anyone who has completed his studies in class A of the school and passes the examination in all disciplines (up to 70 points), is allowed to graduate, and a graduation certificate is issued (Zheng 2019)". In other words, only when students enter the most advanced class $\mathrm{A}$ and pass the exam can they successfully get the graduation certificate.

\subsection{Teaching Achievements of Night Schools}

\subsubsection{Improved Living Conditions for the Urban Working Class}

Ultimately, there were 49 students signed up for the Shanghai YMCA night school. In 1903, it attracted 198 students (Annual Report of CYMCA of Shanghai 1903, p. 2). Since students gained better job opportunities after furthering their study in the Shanghai YMCA night school, there was a spike in the number of students studying at the night school, which peaked at approximately 1437, and more than 300 of them were store apprentices (Editorial Department of Cultural and Historical Data of Shanghai Political Consultative Conference 1996, p. 248). In 1915, the Shanghai YMCA wrote the following on the first page of the Articles of Association for the Business Night School, "It has been decades since the founding of the Shanghai YMCA to this date. Most of those excelling in various groups and institutions graduated from our school. Students achieved excellent scores and obvious learning effects in our school. This has led to a high recognition of our school among walks of all life. Therefore, even if the night school kept on expanding its enrollment, there were still many that did not get enrolled". In 1918, the YMCA's magazine Association Progress published a group photo of Chinese YMCA English Night School Fourth Graduating Class. From Figure 2 we can see that at this time, a class of the English evening school has more than 50 graduates.

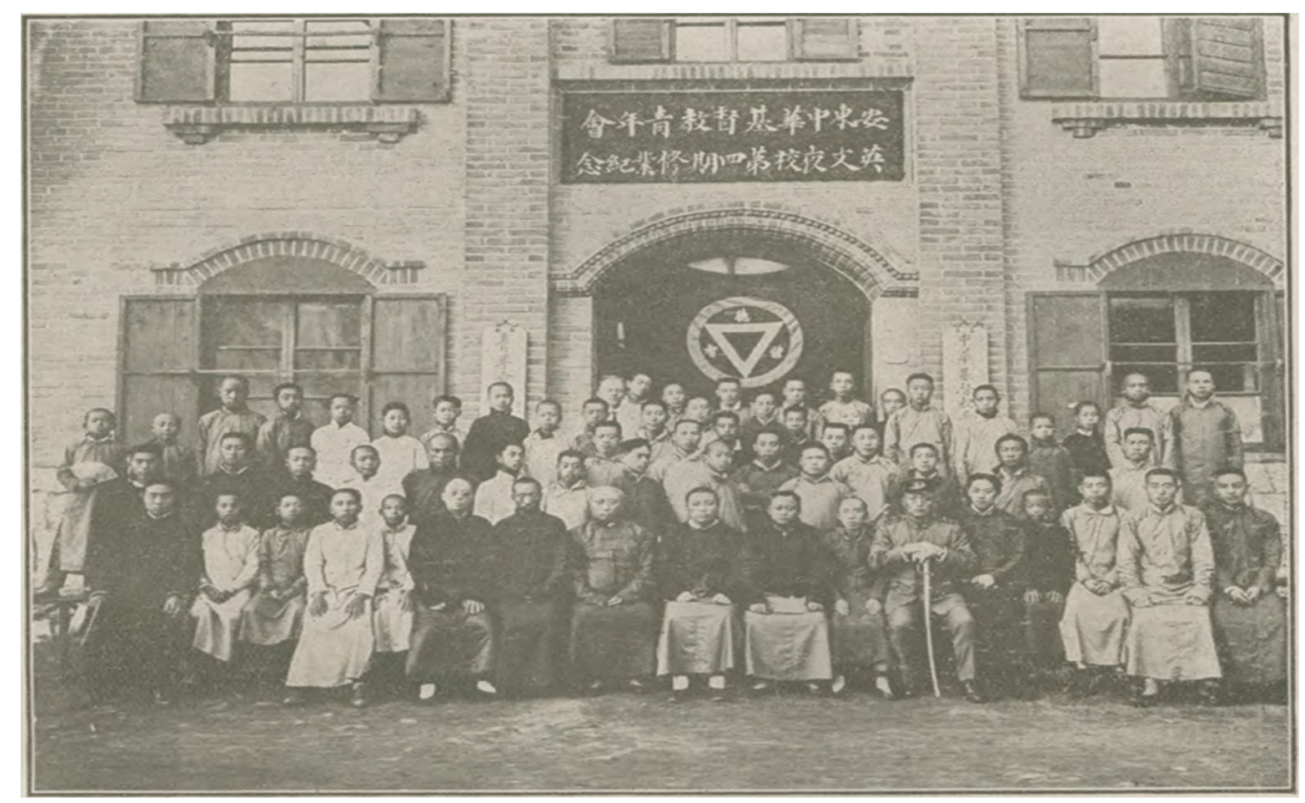

Figure 2. Group photo of the Andong Chinese YMCA English Night School Fourth Graduating Class. Association Progress 1918, 17, 5.

In 1929, the Peking YMCA published its English version of the Articles of Association for the English Night School, which says, "It has been 25 times since the English night school was held, and around 250 students have graduated from the school, many of whom have transferred to other schools for further study and graduated with a well-paid job (7)". In addition to establishing the night school for civilians, the Peking YMCA also innovatively adopted the civilian night school running model, which was created by John Steward Burgess, general secretary of Princeton University and known as the "Father of China's Social Work". On 6 October 1912, more than 40 students from the three church schools and 
three government-run schools in Peking established the Peking Shehui Shijinhui (Society for Social Advancement), which was affiliated with the Peking YMCA (Burgess 1928). Burgess had Peking's grassroots society as the working platform of Shijinhui (Time Progress Association) and combined students' passion for social improvement and social services to creatively establish the YMCA civilian night schools in the residential community (Burgess 1929, 1930). Articles of Association for the English Night School in 1929 shows "so far, we have brought up around five generations of graduates, and the total number of graduates has been counted by the hundreds (1)". Community-based civilian night school played an important role in reducing the number of illiterate people, improving citizens ${ }^{\prime}$ educational level in Peking, bringing up community religious leaders, enhancing residents ${ }^{\prime}$ sense of belonging to the community, etc.

In 1913, the missionary F.O. Leisei of Guangzhou YMCA mentioned in the following in a work report: "Over the past one year, there has been a significant increase in the number of YMCA members. This means the YMCA has become more and more popular. Officials, merchants, students and workers all sincerely support our work. They come to attend our classes, speeches, and sermons and learn at our night school. They support the YMCA's work in their own way, and they also participate in the Bible class to learn the background of Jesus Christ (Guangzhou YMCA 2019, p. 52)". In 1917, the number of people in Bible classes already increased to approximately 1489. According to Leisei's statistics, one-third of the participants in YMCA activities were students, one-third were merchants, and the remaining were workers (Guangzhou YMCA 2019, pp. 168-71).

The Guangzhou YMCA night school earned a growing reputation because it highly satisfied social demand for young unemployed workers. It became a popular choice for poor young men in society. Due to the success of the night school, the Guangzhou YMCA's career also expanded rapidly. So many people have applied to learn at the night school, but because of the limited number of dormitories, they only enroll 80 male and female students (Guangzhou YMCA 2019, p. 278). However, the number of applicants was between 300 and 400, which led to the expansion of the school buildings and dormitories in 1932 to expand its scope. By 1934, the school had even sought to establish branch schools (Guangzhou YMCA 1934).

In 1934, the Guangzhou YMCA conducted a questionnaire survey on graduates of night school in previous years, and found that students "have made remarkable progress in their careers. Some were promoted from executive assistants to office administrators in government institutions, some from school temporary secretaries to regular staff, and some from store apprentices to salesclerks or even managers. Some students, whose family economy is slightly richer, have been successfully admitted to the city's junior middle school or vocational school" (Guangzhou YMCA 1934). Apparently, the personal living conditions of the graduates were greatly improved.

\subsubsection{Nurtured Excellent Representatives}

Cheng Xiaoqing (1893-1976) was a famous Chinese detective fiction writer and foreign detective fiction translator. Cheng was born in a poverty-stricken family in Shanghai, China. His father initially worked in a textile store that closed later, forcing him to sell newspapers in order to feed his family. He died in 1903 under great pressure when Cheng was only ten years old. Cheng's mother was a seamstress and worked hard to ensure that her son was able to go to school. However, severe economic conditions forced Cheng to quit school when he was 15 to help his mother raise his younger sister. At the age of sixteen, Cheng became an apprentice in a watchmaker shop called Hope Brothers and Company in Shanghai (Kinkley 2000; Cheng 2006).

Currently, he is known as the "grand master of China's detective fiction" and the "Conan Doyle in the Eastern world"; in his detective series, the main character, Huo Sang, is considered to be "the Eastern Sherlock Holmes". Readers are obsessed with the fantastic detective fiction written by him. Researchers care about how he brought detective fiction, an emerging writing style from the West, to modern China creatively through translation 
and original writings. However, we wonder how an apprentice from a watch and clock store, born in a family at the bottom of the society and who had dropped out of school in his early years because of impoverishment, could learn English and even scientific knowledge, such as physics and chemistry, and then embarked on the career path as a detective fiction writer.

After retrieving all types of archives, we found that in 1910, Cheng took night classes in the Shanghai YMCA (Cheng 2006, p. 207). At the YMCA night school, Cheng Xiaoqing was not just studying English. Cheng Yuzhen, daughter of Cheng Xiaoqing, recalled the following: "In order to make a living and have a bright future, my father learned many living skills. He is a jack of all trades. He knows how to write, paint, typing, and even play orchestral instruments (Cheng 1944, p. 95)". In the YMCA night school, Cheng Xiaoqing already showed signs of changing his beliefs. From 1921-1927, He published his Chinese poems, translated short stories from English and French on Progressive Youth, a journal of the Shanghai YMCA (See Progressive Youth, Shanghai Library). The predecessor of Progressive Youth was Progress established in Shanghai on 5 November 1911. Hosted by the Shanghai YMCA, the magazine was edited and distributed by the Progress Magazine Agency and had Xi Ruo, Fan Mian and others as its chief editors. After publishing the 4th issue of Volume No. 11 in February 1917, it was combined with a Christian YMCA journal, Youth (See Progress, Shanghai Library). Of special note is that Xi Ruo, the founder of Youth Progress, graduated from Soochow University ${ }^{1}$ in 1907, and he once worked in commercial press as an editor and translator. From 1910 to 1911, Xi Ruo was enrolled in the Theological Seminary at Oberlin, registering his name as Richard Pai-Shou Ye. There, he pursued his master's degree. Then, he worked in the Shanghai YMCA (Jiaohui Zhushujia Xiboshou Xiansheng Xingshu 1916, p. 310). Xi Ruo was the earliest translator to introduce Western detective novels to Chinese. In 1903, Conan Doyle wrote The Return of Sherlock Holmes. In March 1904, Xi Ruo translated the work under the Chinese title “福爾摩斯的重 生", which was published by Novel Forest Publishing House. Therefore, Cheng Xiaoqing's engagement in translating and creating detective novels was highly likely to be directly influenced by this important figure from the Shanghai YMCA.

In 1915, Cheng Xiaoqing went to Soochow to serve as the temporary Chinese teacher in the high school affiliated with Soochow University. There, Cheng developed a deep friendship with the American English teacher Sherejz. They helped each other learn English and Chinese, respectively. This contributed to a significant improvement of Cheng's English proficiency, which gave him the confidence to practice translating literary works (Cheng 2006, p. 208). As a correspondence student in an American university, he also systematically learned criminal investigation and criminal psychology and adopted Forensic Psychology by K. Marbe as the textbook for his writing (Ren 2013, p. 161). In 1916, Cheng and other scholars, such as Zhou Shoujuan, translated the full detective collection of Sherlock Holmes into classical Chinese that was easy to understand. The book was published by the Chinese Bookstore. In 1917, Cheng joined the Southern Methodist Episcopal Church (Cheng 2006, pp. 208-9). Thereafter, under Cheng's leadership, his entire family changed their religious belief to Christianity. He taught his offspring the following: "Treat others with the innocent heart of a child, and forgive those who hurt you. This world is crying for love. Don't ask for rewards, but you should seek comfort for your consciousness. We are Christians, offspring of the God. We should set a good example and treat others benevolently. Though it is impossible for us to gain everyone's recognition, we should not be a stumbling stone to others (Cheng 1944, p. 95)".

Cheng Yuzhen (1921-?), daughter of Cheng Xiaoqing, once studied at Soochow University and Columbia University. As a member of the Soochow female writers' group, she was reputed as the "daughter of the God (Cao 2011, p. 59)". Cheng Yuzhen's religious beliefs and literary creation concepts both directly originated from her father's education. She once recalled the following: "Born and growing up in a Christian family, I have been surrounded by warmth, care and kindness ... My primary school, high school, and college 
were all in church ... Day after day of education has developed my exploratory psychology towards religion (Cheng 1949)".

Cheng Xiaoqing, after publishing the first work, Human Shadow under the Lamplight, wrote 74 detective novels with the personal detective Huosang as the protagonist. Furthermore, he also published a large number of articles discussing theories, guiding the writing of detective novels. Cheng did not directly emphasize his educational background or personal beliefs, which led him, a famous modern Chinese writer brought up by YMCA livelihood education, to be a "Christian falling into oblivion". However, based on external historical materials, the YMCA's change of Cheng's destiny and shaping of his faith had a fundamental influence on Cheng's entire family, and the influence was obvious.

Chen Sisheng (1892-1953), one of the initiators of the China National Democratic Construction Association ${ }^{2}$ in modern China's political circles, was also from the YMCA night school. In 1893, Chen Sisheng was born to a scholarly family. His father Chen Rukang was a Hanlin Academy Shujishi in the late Qing period ${ }^{3}$. Chen Rukang died of a disease when Chen Sisheng was only six years old. After the father's death, Chen's family was in straitened circumstances. Chen Sisheng dropped out before graduating from primary school. In 1908, the 16-year-old Chen Sisheng went to Shanghai, serving as an apprentice in Tongxing Foreign Products Store, where he was mainly responsible for various onerous manual tasks. The YMCA night school gave young and impoverished laborers such as Chen Sisheng an opportunity to receive education. In the same year, he joined the Shanghai YMCA Night School to learn English and business. After acquiring basic skills, such as English and typing, Chen Sisheng was recommended by Zhang Yuanji, an old friend of his father and the then head of the Commercial Press, to work for the Commercial Press Shanghai. Over the two years working for the Commercial Press, he not only participated in and organized all kinds of activities for workers after a day's work but also continued with his work in the YMCA and was formally baptized as a Christian (Wen 2010; Lin 2013; Zhu 2019).

Different from the hidden relationship between Cheng Xiaoqing and the Shanghai YMCA night school, Chen Sisheng, who also graduated from the same night school, gradually developed himself into a backbone member of the Shanghai YMCA. He left many official records in relevant achieves. In 1915, Chen Sisheng joined the Shanghai YMCA on a full-time basis. From 1915 to 1927, he worked for the Shanghai YMCA; and over eight years there, he was promoted from the internal general secretary to the president. In 1924, he was assigned to the Zhengzhou YMCA to work there concurrently as the president. In 1927, upon the recommendation of Yu Rizhang, president of the YMCA National committee, Chen Sisheng obtained the opportunity to travel and study in many European and North American countries. He graduated from Ohio State University and returned to China in 1930. He was appointed vice president of the YMCA national committee ("Former staff member of the YMCA", Anonymous 1924; Wen 2010; Lin 2013; Zhu 2019).

In 1934, Chen Sisheng was appointed the deputy manager of Shanghai Ping'an Shipping Co., Ltd., which symbolized his entry into industrial and commercial circles. In late 1940, Chen Sisheng worked as the deputy general manager of Ningshao Life Insurance Agency (Liu 1999). In 1945, the China Association for Promoting Democracy was established with Chen Sisheng as one of its founders. Later, he was appointed as a central committee member of the national committee of the China Association for Promoting Democracy and as the managing director of the China Association for Promoting Democracy Shanghai. The records on Chen Sicheng during this period mainly focused on his achievements and contributions in commercial circles and political circles, but in fact, he had not cut his connection from the Shanghai YMCA. Instead, he still cared about all types of work of the YMCA and held major posts there. For example, in 1936, he worked as a consultant for the social work of the Shanghai YMCA Four Educational Program. In 1940, he served in the Shanghai YMCA Friends' Consumption and Cooperation Agency as the general supervisor (See related reports in Shanghai Youth). 
In contrast to Chen Xiaoqing, Chen Sisheng never avoided discussing his origins in the YMCA. In 1937, Chen Sisheng wrote an article entitled YMCA and Me in Shanghai Youth, a journal of the Shanghai YMCA. In this article, Chen recalled his life over three decades, including his loss of his father at an early age, his becoming an unaccompanied apprentice, his becoming the president of the Shanghai YMCA and a leader of the commercial circles, and his experience making progress together with the Shanghai YMCA.

"Three decades ago, I was a 16-year-old teenager from the countryside, traveling from the inland to Shanghai to work as an apprentice in a store selling foreign fabrics. With others' guidance, I joined the Shanghai YMCA, becoming a student of its night school. Every day, in addition to working as an apprentice (with my daily chores, including pouring the spittoon, mopping the floor, and cleaning the smoke pipe), I learned knowledge in the YMCA and took part in all kinds of activities that were good for my health. The learning environment of the YMCA became the center of my life. Eventually, I got an opportunity to study religion, which enabled me to learn the truth of Christianity and led to gradual evolution of my ideas. My occupational problems also experienced correct changes. All this was given by the YMCA".

It seems hard to deny that the YMCA night school oriented towards Chinese civilians was, to some extent, the only philanthropic school that youths living at the bottom of society could attend during that period. They acquired skills to make a living and charted the courses of their career again, thus winning opportunities to change their destinies. The excellent ones even had the night school as their springboard to break through various limitations of the class to which they belonged and to hold sway in China's literacy circles, business circles and even political circles. Under the influence of the YMCA night school, they were no longer just seeking survival at the physiological needs level. Instead, love and social belonging needs, cognitive needs, and self-actualization of the education receivers also took shape.

\section{Discussion and Conclusions}

First, YMCA livelihood education was targeted at the poor working people living at the bottom of society and was operated mainly in the form of night school that was more consistent with the working people's schedule. In the history of China, Confucius proposed making no social distinctions in teaching, and under the influence of Confucian traditions, Chinese society advocated the idea that "to be a scholar is to be the top of society"; education was, however, considered a privilege of the elites because of political, economic and cultural restrictions. Before the 20th century, most Chinese civilians were illiterate. In Rawski's Education and Popular Literacy in Ch'ing China, the writer estimated that the literacy rate of $\mathrm{Ch}^{\prime}$ ing China was $30 \%$ to $45 \%$ among males and $2 \%$ to $10 \%$ among females (Rawski 1979, p. 5). However, the Chinese scholar Ge Zhaoguang thought that the statistics were obviously too overestimated. "Even in areas with a developed economy and a high popularization rate of education, the literacy rate was $1 \%$ to $\%$ (Ge 1997, p. 47)". However, it needs to be acknowledged that regardless of whether the specific literacy rate is $2 \%$ or $30 \%$, the illiteracy rate of the Chinese people in the early 20th century was an astonishing number.

With "for God so loved the world" (John 3: 16) and "instructing the apostles to make disciples of all nations" (Matthew 28: 19-20, Mark 16: 15-18) as the purpose and ideal, the YMCA changed the nobles' monopoly on education. The YMCA in China indeed implemented the pursuit of social gospel, that is, "enforced schooling the poor could develop talents and skills, the quality of their moral lives would begin to improve". In addition, it had the aim of combating injustice, suffering, and poverty in society (Schwarz 2005, p. 145). To some extent, the YMCA also availed itself of the power of Western missionaries and churches to implement the educational ideal in Confucian culture.

Additionally, livelihood education was abandoned in China's traditional education system, which focused on Confucian classics learning and put the cultivation of moral quality above science and technology education. With the West, especially the North Amer- 
ican YMCA, as its blueprint, it directly introduced the modern Western educational modes in terms of the system, include institution, plan, curriculum, method, and even regulations. It is a common idea that the modern era of Chinese education began with the country's consecutive defeats in the Opium Wars (1839-1842 and 1856-1860). Many believed that it delivered a fatal blow to the Chinese classical traditions, defeats demonstrated China's backwardness in terms of its scientific and technological achievement (Edmunds 1919; Peake 1970). Thus, modernization was deemed necessary (Fairbank et al. 1973).

From 1919, leaders of the New Culture Movement believed that Chinese nationalists called for a rejection of traditional values and the adoption of Western ideals of "Mr. Science" and "Mr. Democracy" in place of "Mr. Confucius" in order to strengthen the new nation (Spence 1982, pp. 117-23). In contrast, the YMCA livelihood education that appeared earlier than the new culture movement was based on the language teaching of Britain, France, Germany, and other foreign countries and with practical courses, including accounting, mathematics, industrial chemistry, wireless electricity, business law, and others as its subjects. YMCA night school was the early modern education model in China that played an exemplary and guiding role in China's modernization process to some extent. Night school not only accelerated the spread of new Western ideas and technologies but also promoted the modernized transformation of Chinese society.

As we can see, by learning at YMCA night school, Cheng Xiaoqing developed the idea of saving the country through science. Specifically, he spread basic scientific knowledge among the masses through detective novels that were claimed by him to be "popular science textbooks" to wake up the people fooled around by the ruler. Chen Sisheng attached greater emphasis to practice in the political field. As the founder of one of the eight democratic party groups in China and a famous democratic personage outside the party system, he made considerable efforts to establish China's political consultation system.

However, as shown in the second part, we are surprised to find that YMCA livelihood education, despite its numerous contributions stated above, failed to gain equal emphasis and praise, which, on the contrary, even aroused suspicions. Christian doctrines permit the provision of aid without requiring religious conversion (Luke 9:51-56; Luke 10:25-37). The YMCA night school in China helped improve the economy, education, and medical care of the Chinese without rigidly connecting these activities with Christian beliefs. In addition, the night school did not ever make willingness to join Christianity as a basic requirement for students to enroll.

Shiner (1967) described five forms of secularization, including the following: is it a subversion of Islam or Christianity that one becomes increasingly concerned with the good life in "this world" (212). Secularization refers in the first instance to the development of a secular or nonreligious realm alongside the world informed by religion; however, during the course of modernity, it has come to mean the expansion and dominance of the secular realm and the concomitant diminution or disappearance of the contradictions of the enlightenment sphere of religion (Gillespie 2008, pp. 270-71).

YMCA livelihood education emphasized training in living skills irrelevant to religious beliefs and the market-oriented economy, which became more consistent with modern society in terms of both content and form. Consequently, it resulted in the basis of the YMCA's undertakings and resources in secular fields, thus blurring the boundary between Christianization and secularization. This decline in the importance of religion and theology in livelihood education was characterized as the process of secularization and caused the loss of the legitimacy of missionary activities and obsessions with missioners' identity (Huang 2013, pp. 95-99). For example, some research holds that the appearance of night schools for workers made it possible for poor people living at the bottom of society to select their occupation again and gain the ability to eliminate suppression. As an important turn in China's missionary undertaking, it symbolized the start of deviating from the education that cared only about Christianity and the start of being more closely combined with practical situations in China (Honig 1996, p. 225). The emergence and development of livelihood education was otherwise a challenge and wavering of Christianity in China. Therefore, 
the critics mainly concentrated on YMCA livelihood education, whose curriculum design had striking secular and social characteristics that had already deviated from what the YMCA, a Christian organization, should obey, that is, to regard the spreading of gospels and attracting new followers at the core of its fundamental goal. From another perspective, in some ways, these arguments reflect the debates between fundamentalism and liberal Christianity worldwide in the 20th century.

In contrast, we found that the designers of YMCA night schools never ignored Christian missions because they emphasized livelihood education. We also noticed that Bible classes were a primary course of the YMCA night school in Shanghai, Peking, and Guangzhou, which aroused many people's interest in Christianity. Multiple general secretaries of the YMCA also made it clear that the biggest problem was in how the YMCA should win men to Christianity—not by special gatherings but by daily work (Guangzhou YMCA 2019, p. 77).

In the 1917 annual, the general secretary, M. A. Kees, named the relaunched night school the "Guangzhou YMCA". The Guangzhou YMCA enjoyed sound development momentum. "After the launch of the new church, we have been trying to set up night schools. Business English courses are particularly popular, which enables us to reach those who have no way of learning Christianity. These learners are from trading companies, customs, railway departments, governments, banks, stores, etc. The most satisfactory Bible class that I have taught consists of students from the above backgrounds. As an important part of our intellectual education, the Bible class makes gospel messages more acceptable to these students (Guangzhou YMCA 2019, p. 189)". The night school attracted youths to further create opportunities to spread the gospels so that they could believe in Christianity. This was the main way for the night school to preach Christianity. G.E. Lerrigo, a foreign general secretary of the Guangzhou YMCA, developed Ng Hou, who just wanted to learn English, into a devoted Christian and reported it as an important achievement of religious work to the headquarters of the United States (Guangzhou YMCA 2019, p. 131).

In addition, the teaching objectives of YMCA night schools included not only literacy, livelihood and civic education, but also the last one, cultivating student's morality, which reflects the mission of YMCA, which always emphasizes Christian "moral education". In fact, moral values, such as compassion, unconditional love, dedication and kindness, were built into all the lessons. In brief, the YMCA night school provided a range of vocational training pathways for students. However, the acquisition of practical and personal skills in school was only one goal of education. Another primary goal of education was teaching students Christian morality to prepare them to be standard citizens in the modern society.

Hence, some students once claimed their learning experience in the YMCA night school involved a search for individual meaning that went on in the church. Their beliefs could generally build a connection between the YMCA and Christianity. Christianity as a deeper level factor that underlies the development of livelihood education shapes a certain recurrent pattern, first from the education on making a living, and then, students were included by the YMCA in the civilization system of the modern world, YMCA changed their ideas to establish a new belief framework. This was a classical route for the YMCA livelihood education to develop Christianity.

This study has some limitations. The existing historical materials were very limited, and many people who received education at the YMCA night school during the same period, either actively or passively, avoided discussion or even denied this experience. This requires more prudence from us while drawing any conclusion. In the future, we hope that we can further extend the scope of this research and turn this paper into part of a larger research plan with more diversified and multilingual historical materials included. We will not only discuss the Chinese YMCA and China's education in the early 20th century but also hope that we can propose more noteworthy new cases for the spread, evolution, and development of religious education in the world. 
Author Contributions: Conceptualization, Y.Y. and X.L.; Methodology, Y.Y.; Investigation, K.-Y.K. and X.L.; Writing—original draft preparation, Y.Y.; Writing—review and editing, Y.Y and X.L. All authors have read and agreed to the published version of the manuscript.

Funding: This research received no external funding.

Institutional Review Board Statement: Not applicable.

Informed Consent Statement: Not applicable.

Conflicts of Interest: The authors declare no conflict of interest.

\section{Notes}

1 The original Soochow University (Chinese: 東吳大學) was founded by the Methodist Episcopal Church, South in Suzhou in 1900.

2 The China National Democratic Construction Association (CNDCA), sometimes translated as the China Democratic National Construction Association (CDNCA), also known by its Chinese abbreviation Minjian (民建), is one of the eight legally recognized minor political parties in the People's Republic of China that follow the direction of the Chinese Communist Party and are members of the Chinese People's Political Consultative Conference. It was founded in Chongqing in 1945 by the Vocational Education Society, a former member of the China Democratic League.

3 The Hanlin Academy was an academic and administrative institution founded in the eighth-century Tang China by Emperor Xuanzong in Chang'an. Membership in the academy was confined to an elite group of scholars who performed secretarial and literary tasks for the court. One of its main duties was to interpret Chinese classics. Shujishi (Chinese: 庶吉士), which means “all good men of virtue", is a scholastic title from the Ming and Qing dynasties of China. It can be used to denote a group of people who hold this title and individuals who possess the title.

\section{References}

Annual Report of Chinese Young Men's Christian Association of Shanghai. 1901. Records of YMCA International Work in China, Kautz Family YMCA Archives. Minneapolis: University of Minnesota Libraries.

Annual Report of Chinese Young Men's Christian Association of Shanghai. 1903. Records of YMCA International Work in China, Kautz Family YMCA Archives. Minneapolis: University of Minnesota Libraries.

Anonymous. 1912. Zhongguo Qingnianhui Banye Xuetang Xinhai Jianzhang 中國青年會半夜學堂辛亥簡章 [Articles of YMCA for the Night School]. Shanghai: Shanghai YMCA.

Anonymous. 1915. 'Shangye Xuexiao Banye Xuetang Zhangcheng' 商業學校半夜學堂章程 [Articles of YMCA for the Business Night School]. Shanghai: Shanghai YMCA Business Night School.

Anonymous. 1924. Gong Kedan 功課單 [Homework Sheet]. Shanghai YMCA News, October 23.

Bai, Yu Cheng. 2020. God's Model Citizen: The Citizenship Education Movement of the YMCA and Its Political Legacy. Studies in World Christianity 26: 42-62. [CrossRef]

Bean, Ryan. 2012. Selling the Mission: The North American YMCA in China 1890-1949. Taiwan: National Central University, Retrieved from the University of Minnesota Digital Conservancy. Available online: https://hdl.handle.net/11299/140888 (accessed on 14 August 2021).

Burgess, John Stewart. 1928. The Guilds of Peking. New York: Columbia University Press.

Burgess, John Stewart. 1929. Certain Concepts, Methods and Contributions in the Social Science and Social Philosophy of LT Hobhouse. The Chinese Social and Political Science Association 13: 119.

Burgess, John Stewart. 1930. The guilds and trade associations of China. The ANNALS of the American Academy of Political and Social Science 152: 72-80. [CrossRef]

Cao, Xiao Hua. 2011. Shangdizhinv tazhongmeigui-Lun chengy zhen de wen ue chuangzuo 上帝之女 塔中玫瑰一論程育真的文學創 作 [The Rose in the Tower and God's Daughter-On Cheng Yuzhen's Literary Creation]. Journal of Ningbo Institute of Education 13: 59-63.

Chen, Litin 陳立廷. 1927. ‘Qingnianhui zhi jiaoyu diwe' 青年會之教育地位 [The Status of Youth Education]. Shanghai Qingnian 上海青年 [Shanghai Youth] 26: 1.

Cheng, Yuzhen 程育真. 1944. 'Fuqin' 父親 [Father]. Xiaoshuo Yuebao 小説月報 [Fiction Monthly] 45: 93-98.

Cheng, Yuzhen 程育真. 1949. 'lvcheng Riji' [旅程日記]. Zhongmei Zhoubao 中美週報, Sino-American Weekly, February 24.

Cheng, Xiao Qing. 2006. About Cheng Xiaoqing. In Sherlock in Shanghai: Stories of Crime and Detection by Cheng Xiaoqing. Honolulu: University of Hawaii Press.

China YMCA National Association 中華基督教青年會全國協會編, ed. 1935. Zhonghua Jidujiao Qingnia Hui Wushi Zhounian Jiniance (1885-1935) 中華基督教青年會五十週年紀念冊 (1885-1935) [China YMCA 50th Anniversary Memorandum (1885-1935)]. Shanghai: China YMCA National Association.

Chung, Chung Cheuk-Chi. 2019. Politicized Faith: The Transformation of the Discourse" Character, China's Salvation" of the Chinese YMCA, 1908-1927. Ching Feng 18: 123-47. 
Editorial Department of Cultural and Historical Data of Shanghai Political Consultative Conference, ed. 1996. 上海市政協文史資料編輯 部編 'Shanghai de Zongjiao' 上海的宗教 [Religion in Shanghai]. Shanghai: Xinhua Bookstore.

Edmunds, Charles K. 1919. Modern education in China. The Journal of International Relations 10: 62-86. [CrossRef]

Fairbank, John King, Edwin O. Reischauer, and Albert M. Craig. 1973. East Asia: Tradition and Transformation. London: Allen \& Unwin. Garrett, Shirley S. 1970. Social Reforms in Urban China: The Chinese Y.M.C.A., 1895-1926. Cambridge: Harvard University Press.

Ge, Zhao Guang. 1997. 'Shixiantongshu de yiwei' 《時憲通書》的意味 [The meaning of Shixiantongshu]. Dushu 讀書 [Reading] 1997: $43-48$.

Gillespie, Michael Allen. 2008. The Theological Origins of Modernity. Chicago: University of Chicago Press.

Goldman, Merle, and Elizabeth J. Perry, eds. 2002. Changing Meanings of Citizenship in Modern China. Cambridge: Harvard University Press.

Guangzhou YMCA, ed. 1934. Guangzhou Qingnian. Guangzhou: Guangzhou YMCA.

Guangzhou YMCA, ed. 2019. Annual Report of Guangzhou Y.M.C.A. Beijing: Religious Culture Publishing House.

Hayford, Charles Wishart. 1979. Rural Reconstruction in China: YC James Yen and the Mass Education Movement. Cambridge: Harvard University.

Honig, Emily. 1996. Christianity, Feminism, and Communism: The Life and Times of Deng Yuzhi. In Christianity in China: From the Eighteenth Century to the Present. Edited by Daniel H. Bays. Stanford: Stanford University Press, pp. 243-62.

Huang, Hai Bo. 2013. Zongjiao Feiyingli Zuzhide Shenfenjiangou Yanjiu: Yi Shanghai Jidujiao Qingnianhui Weili 宗教性非盈利組織的身份建 構研究 [Research on the Identity Construction of Religious Nonprofit Organizations: A Case Study of the Shanghai YMCA]. Shanghai: Shanghai Academy of Social Sciences Press.

Jiaohui Zhushujia Xiboshou Xiansheng Xingshu 教會著述家奚伯綬先生行述. [The introduction of the Church publisher Xi Boshou]. 1916. Zhonghua Jidujiaohui Nianjian 中華基督教會年監 [Yearbook of the Christian Church of China]. Shanghai: The Commercial Press.

Kinkley, Jeffrey C. 2000. Chinese Justice, the Fiction: Law and Literature in Modern China. Stanford: Stanford University Press.

Lin, Lv Jian 林呂建. 2013. Zhejiang Min'guo Renwu Dacidian 浙江民國人物大辭典 [Dictionary of People in the Republic of Zhejiang]. Zhejiang: Zhejiang University Press.

Liu, Jing Quan, ed. 1999. Zhongguo Kangri Zhanzheng Renwu Dacidian 中國抗日戰爭人物大詞典 [Dictionary of Chinese People in AntiJapanese War]. Tianjin: Tianjin University Press.

Peake, Cyrus Henderson. 1970. Nationalism and Education in Modern China. New York: H. Fertig.

Peking YMCA, ed. 1929. Beijing Jidujiao Qingnianhui Yingwen Yexiao Zhangcheng 北京基督教青年會英文夜校章程 [Articles of Association for the English Night School]. Beijing: Peking YMCA.

Perry, Elizabeth J. 1993. Shanghai on Strike: The Politics of Chinese Labor. Stanford: Stanford University Press.

Rawski, Evelyn S. 1979. Education and Popular Literacy in Ch'Ing China. Ann Arbor: University of Michigan Press.

Ren, Xiang, ed. 2013. Zhongguo Zhentan Xiaoshuo Lilun Ziliao 中國偵探小説理論資料 [Theoretical Materials of Chinese Detective Novels]. Beijing: Beijing Normal University Press.

Schwarz, Hans. 2005. Theology in a Global Context: The Last Two Hundred Years. Grand Rapids: W.B. Eerdmans Publishing.

Shiner, Larry. 1967. The concept of secularization in empirical research. Journal for the Scientific Study of Religion 6: 207-20. [CrossRef]

Spence, Jonathan D. 1982. The Gate of Heavenly Peace: The Chinese and Their Revolution, 1895-1980. London: Faber \& Faber Ltd.

Wang, Dong. 2005. China's Unequal Treaties: Narrating National History. Lanham: Lexington Books.

Wen, Zhou. 2010. 'Chen Sisheng yu Shanghai Minjian' 陳巳生與上海民建 [Chen Sisheng and the Shanghai Committee of China National Democratic Construction Association]. 'Shanghai Minjian Lishi Dang'an'上海民建歷史檔案 [Historical Archives of the Shanghai Committee of China National Democratic Construction Association]. Available online: http://www.mjshsw.org.cn/n2 967/n2973/n3186/u1ai1818522.html (accessed on 15 January 2021).

Xing, Jun. 1993. Baptized in the Fire of Revolution: The American Social Gospel and the YMCA in China: 1919-1937. Doctoral dissertation, University of Minnesota, Minnesota, MN, USA.

Zhang, Zhi Wei. 2010. Jiduhua yu Shisuhuade Zhengzha, 1900-1922: Shanghai Jidujiao Qingnianhui Yanjiu [The Struggle between Christianization and Secularization, 1900-1922: Research on the Shanghai YMCA]. Taipei: National Taiwan University Press.

Zheng, Li Qun. 2019. Sinicization and Professionalization: YMCA and Modern Civilian Education: With the Guangzhou YMCA as an Example. Revista do Instituto Politécnico de Macau 73: 95-104.

Zhu, Shan Jiu. 2019. 'Chen Si Sheng yu Chen Zhen Zhong' 陳巳生與陳震中 [Chen Sisheng and Chen Zhengzhong]. Beijing: Chinese Literature and History Press.

Zuo, Fu Rong. 2003. Social Gospel and Social Service: A Case Study of Peking YMCA (1909-1949). Doctor's dissertation, The Chinese University of Hong Kong, Hong Kong, China. 